\title{
FAKTOR-FAKTOR YANG MEMPENGARUHI PARTISIPASI KADER JUMANTIK DALAM MELAKSANAKAN PEMBERANTASAN SARANG NYAMUK DI KECAMATAN DENPASAR SELATAN
}

\author{
I Made Oka Cahyadi*, Sang Gede Purnama \\ Program Studi Ilmu Kesehatan Masyarakat Fakultas Kedokteran Universitas Udayana \\ *email : okacahyadi07@gmail.com
}

\begin{abstract}
ABSTRAK
Kecamatan Denpasar Selatan merupakan kecamatan dengan kasus DBD tertinggi di Kota Denpasar. Dalam 3 tahun terakhir perkembangan kasus Demam Berdarah Dengue (DBD) di Kecamatan Denpasar Selatan, yaitu 1,074 kasus pada tahun 2016, 290 kasus di tahun 2017 dan 33 kasus di tahun 2018. Pembentukan Juru Pemantau Jentik (Jumantik) oleh Pemerintah Kota Denpasar diharapkan dapat menurunkan angka kasus DBD di Kota Denpasar. Penelitian ini bertujuan untuk mengetahui karakteristik partisipasi kader Jumantik serta faktor-faktor yang mempengaruhi partisipasi kader Jumantik dalam melaksanakan PSN di Kecamatan Denpasar Selatan. Rancangan penelitian ini adalah cross sectional dengan jumlah sampel 105 dengan teknik pengambilan sampel menggunakan metode exhaustive sampling dimana seluruh populasi yang ada digunakan sebagai sampel agar tidak menimbulkan persepsi diskriminasi. Hasil penelitian menunjukkan sebanyak 96 responden (91,4\%) tergolong memiliki partisipasi aktif dan 9 responden $(8,6 \%)$ tergolong kurang aktif. Faktor-faktor yang berpengaruh terhadap partisipasi kader Jumantik antara lain pendidikan, penghasilan, ketersediaan sarana, dukungan keluarga, masa kerja, usia, pengetahuan dan pengawasan. Sedangkan faktor pemberian penghargaan dan dukungan masyarakat tidak berpengaruh terhadap partisipasi kader Jumantik dalam melaksanakan PSN di Kecamatan Denpasar Selatan.
\end{abstract}

Kata Kunci : Demam Berdarah Dengue, Jumantik, Partisipasi

\begin{abstract}
South Denpasar District is a sub-district with the highest DHF cases in Denpasar City. In the last 3 years the development of cases of Dengue Hemorrhagic Fever (DHF) in South Denpasar Subdistrict, which is 1,074 cases in 2016, 290 cases in 2017 and 33 cases in 2018. The formation of the Jumantiks by the Denpasar City Government is expected to reduce the cases of dengue fever in Denpasar city. This study aims to determine the participation characteristics of Jumantiks cadres and the factors that influence the participation of Jumantiks cadres in implementing PSN in South Denpasar District. The design of this study was cross sectional with a sample size were 105 cadres with the sampling technique using an exhaustive sampling method where all existing populations were used as samples so as not to cause perceptions of discrimination. The results showed that 96 respondents (91.4\%) belonged to active participation and 9 respondents $(8.6 \%)$ were classified as less active. Factors that influence the participation of Jumantik cadres include education, income, availability of facilities, family support, years of work, age, knowledge and supervision. While the factors of giving awards and community support did not affect the participation of Jumantik cadres in implementing PSN in South Denpasar District.
\end{abstract}

Key Words : Dengue Hemorrhagic Fever, Jumantik, Participation

\section{PENDAHULUAN}

\section{Perkembangan penyakit Demam}

Berdarah Dengue (DBD) cukup tinggi dan menyebar di seluruh wilayah Indonesia. Sejak tahun 1968 sampai tahun 2009, World Health Organization (WHO) mencatat
Indonesia merupakan negara dengan kasus Demam Berdarah Dengue (DBD) tertinggi di kawasan Asia Tenggara. Dilaporkan terjadi peningkatan kasus Demam Berdarah Dengue (DBD) di Indonesia, yaitu 58,065 kasus terjadi pada tahun 2011 dan meningkat 
Vol. 7 No. 2 : 21 - 34

menjadi 74,062 kasus di tahun 2012. Angka kesakitan (Insident Rate) akibat penyakit Demam Berdarah Dengue (DBD) di Indonesia menduduki peringkat pertama di kawasan Asia Tenggara, yaitu 52,5\%.(Sukowati, 2010).

Perkembangan kasus Demam Berdarah Dengue (DBD) di Kota Denpasar cukup tinggi tiap tahunnya. Pada tahun 2016 jumlah kasus DBD di Kota Denpasar sebanyak 2.851 kasus. Pada tahun 2017 jumlah kasus DBD sebanyak 928 kasus. Pada tahun 2018 terdapat 113 kasus. Dan sepanjang tahun 2019 hingga Bulan Februari 2019 sudah terdapat 208 kasus. Dari jumlah tersebut, Kecamatan Denpasar Selatan merupakan salah satu penyumbang kasus DBD terbesar di Kota Denpasar. Pada tahun 2016 jumlah kasus DBD di Kecamatan Denpasar Selatan sebanyak 1.074 kasus, kemudian pada tahun 2017 terdapat 290 kasus dan pada tahun 2018 terdapat 33 kasus.

Berbagai upaya dilakukan Pemerintah Kota Denpasar untuk menekan angka kasus Demam Berdarah Dengue (DBD), khusunya di Kota Denpasar. Salah satu upaya yang dilakukan adalah dengan membentuk Juru Pemantau Jentik (Jumantik) yang ditugaskan untuk memantau jentik di rumah-rumah warga dan tersebar di seluruh Banjar/Dusun di Kota Denpasar. Selain bertugas memantau jentik ke rumah-rumah warga para kader Jumantik ini juga memberikan informasi kepada warga untuk ikut melakukan kegiatan Pemberantasan Sarang Nyamuk (PSN) di lingkungan tempat tinggalnya. Hal ini bertujuan untuk meningkatkan partisipasi dan kemandirian masyarakat untuk berperan serta menjaga lingkungan di sekitar tempat tinggalnya dengan melakukan kegiatan PSN, sehingga perkembangan kasus Demam Berdarah Dengue (DBD) dapat ditekan.

Kehadiran kader Jumantik sangat penting dalam upaya pencegahan kasus Demam Berdarah Dengue (DBD). Mengingat para kader tersebut langsung berhadapan dengan masyarakat dalam upaya Pemberantasan Sarang Nyamuk (PSN) dan memberikan Komunikasi Informasi dan Edukasi (KIE) kepada warga untuk ikut melaksanakan kegiatan PSN di lingkungan tempat tinggalnya. Dalam kesehariannya tidak semua kader Jumantik dapat berperan aktif untuk melaksanakan tugasnya. Hal tersebut dapat dilihat dari absensi, perkembangan kasus maupun ketepatan kader Jumantik tersebut dalam mengirimkan laporan. Menurut penelitian Pambudi tahun 2009 ada beberapa faktor yang mempengaruhi partisipasi kader Jumantik untuk melaksanakan kegiatan PSN, seperti penghasilan, pendidikan dan jenis pekerjaan. Berdasarkan pada latar belakang tersebut, maka dalam penelitian ini, peneliti ingin meneliti lebih lanjut faktor-faktor yang mempengaruhi partisipasi Kader Jumantik dalam melaksanakan PSN di Wilayah Kerja Puskesmas di Kecamatan Denpasar Selatan.

\section{METODE PENELITIAN}

Penelitian ini merupakan penelitian deskriptif dengan rancangan cross sectional. Penelitian ini dilaksanakan terhadap kader 
Jumantik yang terdaftar di Kecamatan Denpasar Selatan pada bulan April-Mei 2019. Jumlah sampel dalam penelitian ini sebanyak 105 responden yang sesuai dengan jumlah kader Jumantik di Kecamatan Denpasar Selatan. Teknik teknik pengambilan sampel menggunakan metode exhaustive sampling dimana seluruh populasi yang ada digunakan sebagai sampel agar tidak menimbulkan persepsi diskriminasi (Murti, 2006). Sampel yang diambil adalah yang memenuhi kriteria inklusi, yaitu terdaftar sebagai kader Jumantik di Kecamatan Denpasar Selatan, berpartisipasi dalam kegiatan Jumantik di Kecamatan Denpasar Selatan, dapat berkomunikasi secara verbal, atau dapat membaca dan menulis serta bersedia djadikan sebagai responden dengan menandatangani surat pernyataan. Sedangkan kriteria ekslusinya adalah kader yang tidak memenuhi kriteria inklusi dan atau yang tidak bersedia dijadikan sebagai responden.

Cara pengumpulan data dalam penelitian ini adalah dengan menggunakan kuesioner. Dalam penelitian ini masingmasing responden diberikan dua buah kuesioner untuk dijawab. Kuesioner pertama berisi pertanyaan-pertanyaan untuk mengetahui partisipasi kader Jumantik, sedangkan kuesioner kedua berisi pertanyaan tentang faktor-faktor yang mempengaruhi partisipasi kader Jumantik dalam melaksanakan PSN. Data kemudian dianalisi menggunakan aplikasi SPSS. Analisa dilakukan dua kali, yaitu analisis univariat untuk mengetahui karakteristik dan proporsi tingkat partisipasi kader Jumantik dalam melaksanakan PSN di Kecamatan Denpasar Selatan. Kemudian dilanjutkan dengan analisis bivariat, yang menguji masing-masing variabel untuk mengetahui faktor-faktor yang berpengaruh terhadap partisipasi kader Jumantik dalam melaksanakan PSN di Kecamatan Denpasar Selatan.

\section{HASIL}

Responden dalam penelitian ini adalah kader Jumantik yang terdaftar di Kecamatan Denpasar Selatan tahun 2019. Jumlah responden sebanyak 105 kader, jumlah ini diperoleh melalui uji pendahuluan mengenai partisipasi dari para kader Jumantik dalam melaksanakan PSN di wilayah kerja Puskesmas di Kecamatan Denpasar Selatan selama 1 bulan terakhir. Data distribusi frekuensi yang peneliti peroleh mengenai karakteristik dan tingkat partisipasi dari para kader Jumantik berdasarkan analisis univariat akan dijelaskan sebagai berikut

Tabel 1. Hasil Analisis Univariat Karakteristik Kader Jumantik di Kecamatan Denpasar Selatan

\begin{tabular}{|c|c|c|}
\hline Variabel & Frekuensi & Persentase \% \\
\hline \multicolumn{3}{|c|}{ Tingkat Pendidikan } \\
\hline Tinggi & 91 & 86,7 \\
\hline Rendah & 14 & 13,3 \\
\hline
\end{tabular}


Oka Cahyadi \& Gede Purnama

Vol. 7 No. 2 : 21 - 34

Penghasilan

Cukup $\quad 51$

48,6

Kurang

54

51,4

Penghargaan

Ada

103

98,1

Tidak

Ketersediaan Sarana

$\begin{array}{ll}\text { Cukup } & 105\end{array}$

100

Kurang

Dukungan Masyarakat

Ada

88,6

Tidak

Dukungan Keluarga

Ada

Tidak

\section{Masa Kerja}

Lama

Baru

Usia

Dewasa

96

91,4

Belum Dewasa

Pengetahuan

Tinggi

Rendah

Pengawasan dari Pimpinan

Ada

96

91,4

Tidak

9

8,6

Partisipasi

Aktif

96

91,4

Kurang aktif

9

8,6

Berdasarkan Tabel. 1 diketahui bahwa karakteristik pendidikan kader Jumantik di Kecamatan Denpasar Selatan, yaitu sebanyak 91 orang $(86,7 \%)$ berada dalam katagori pendidikan tinggi, 14 orang $(13,3 \%)$ berada dalam katagori rendah. Berdasarkan pada tabel tersebut diketahui bahwa sebagian besar responden berpendidikan tinggi (lulusan SMA/Sederajat dan Perguruan Tinggi) sebanyak 91 orang $(86,7 \%)$.

Berdasarkan pengahasilan yang diterima sebagai kader Jumantik sebanyak 
51 responden $(48,6 \%)$ menganggap bahwa penghasilan yang diterima sebagai kader Jumantik adalah cukup dan 54 responden $(51,4 \%)$ menganggap bahwa penghasilan yang diterima sebagai kader Jumantik kurang cukup. Berdasarkan pada tabel tersebut diketahui bahwa sebagian besar responden menganggap penghasilan yang diterima sebagai kader Jumantik adalah kurang cukup, yaitu sebanyak 54 orang (51,4\%). Berdasarkan aspek penghargaan yang diterima selama bekerja sebagai kader Jumantik diketahui bahwa sebanyak 103 orang responden (98,1\%) menganggap penghargaan yang diterima dari pimpinan cukup dan sebanyak 2 responden (1,9\%) mengaku penghargaan yang diterima dari pimpinan kurang cukup. Berdasarkan tabel tersebut diketahui bahwa sebagian besar responden menganggap penghargaan yang diterima dari pimpinan cukup, yaitu sebanyak 103 orang $(98,1 \%)$.

Dilihat dari aspek ketersediaan sarana diketahui bahwa sebanyak 105 orang responden (100\%) menganggap ketersediaan sarana yang diterima sebagai kader Jumantik adalah cukup. Dari faktor dukungan masyarakat diketahui bahwa sebanyak 93 responden $(88,6 \%)$ mendapat dukungan baik dari masyarakat dan sebanyak 12 responden $(11,4 \%)$ tidak mendapatkan dukungan baik dari masyarakat. Berdasarkan tabel tersebut diketahui bahwa sebagian besar kader Jumantik mendapatkan dukungan baik dari masyarakat, yaitu sebanyak 93 orang responden (88,6\%). Dari variabel dukungan keluarga diketahui bahwa sebanyak 86 responden $(81,9 \%)$ mendapatkan dukungan baik dari keluarga sedangkan sebanyak 19 orang responden $(18,1 \%)$ tidak mendapatkan dukungan baik dari keluarga. Berdasarkan tabel tersebut diketahui bahwa sebagian besar responden mendapatkan dukungan baik dari keluarga, yaitu sebanyak 86 orang $(81,9 \%)$. Dilihat dari masa kerja sebagai kader Jumantik diketahui bahwa sebanyak 13 responden $(12,4 \%)$ berada dalam katagori masa kerja baru dan 92 responden $(87,6 \%)$ berada dalam masa kerja lama. Berdasarkan dalam tabel tersebut diketahui bahwa sebagian besar responden berada dalam kategori masa kerja lama sebanyak 92 orang (87,6\%).

Dilihat dari katagori kelompok usia diketahui bahwa 96 responden (91,4\%) responden dengan kategori usia dewasa dan sebanyak 9 orang responden $(8,6 \%)$ berada dalam usia belum dewasa. Usia terendah kader Jumantik berada dalam usia 20 tahun dan usia tertinggi adalah usia 61 tahun. Berdasarkan tabel tersebut diketahui bahwa sebagian besar responden berada dalam usia dewasa, yaitu sebanyak 96 orang (91,4\%). Berdasarkan tingkat pengetahuan responden diketahui bahwa responden dengan pengetahuan tinggi sebanyak 89 orang responden $(84,8 \%)$ dan 16 orang responden $(15,2 \%)$ dengan pengetahuan rendah. Berdasarkan pada tabel tersebut diketahui bahwa sebagian besar responden memiliki tingkat pengetahuan tinggi, yaitu sebanyak 89 orang (84,8\%). Berdasarkan indikator pengawasan dari pimpinan yang menganggap pengawasan dari pimpinan 
cukup terdapat 96 orang responden (91,4\%) dan 9 responden $(8,6 \%)$ menganggap pengawasan dari pimpinan kurang cukup. Berdasarkan pada tabel tersebut diketahui bahwa sebagian besar responden menganggap pengawasan dari pimpinan cukup, yaitu sebanyak 96 orang (91,4\%).

Dilihat dari partisipasi kader Jumantik dalam melaksanakan PSN diketahui bahwa sebanyak 96 responden (91,4\%) berada dalam katagori aktif dan 9 responden $(8,6 \%)$ berada dalam kategori kurang aktif. Berdasarkan pada tabel tersebut diketahui bahwa kader Jumantik yang memiliki partisipasi kurang aktif sebanyak 9 responden (8,6\%). Analisis bivariat dilakukan untuk mengetahui hubungan antara variabel bebas dengan variabel terikat dengan menggunakan uji Chi Square dengan tingkat kepercayaan 95\% $(\mathrm{p}=0,05 \%)$. Adapun hasil analisis bivariat pada masing-masing variabel dalam penelitian ini dijelaskan sebagai berikut.

Tabel 2. Hasil Analisis Bivariat Faktor-Faktor Yang Mempengaruhi Partisipasi Kader Jumantik Di Kecamatan Denpasar Selatan

\begin{tabular}{|c|c|c|c|c|c|}
\hline \multirow[t]{2}{*}{ Variabel } & \multicolumn{2}{|c|}{ Partisipasi } & \multirow{2}{*}{$\begin{array}{l}\text { Crude } \\
\text { OR }\end{array}$} & \multirow[t]{2}{*}{$95 \%$ CI } & \multirow{2}{*}{$\begin{array}{l}\text { Nilai } \\
\mathbf{P}\end{array}$} \\
\hline & Aktif & Kurang aktif & & & \\
\hline \multicolumn{6}{|c|}{ Tingkat pendidikan } \\
\hline Tinggi & $86(94,5 \%)$ & $5(5,5 \%)$ & 6.880 & $1.584-29.888$ & 0,004 \\
\hline Rendah & $10(71,4 \%)$ & $4(28,6 \%)$ & & & \\
\hline \multicolumn{6}{|l|}{ Penghasilan } \\
\hline Cukup & $50(98 \%)$ & $1(2 \%)$ & 8,696 & $1,047-72,223$ & 0,019 \\
\hline Kurang & $46(85,2 \%)$ & $8(14,8$ & & & \\
\hline \multicolumn{6}{|l|}{ Penghargaan } \\
\hline Cukup & $94(91,3 \%)$ & $9(8,7 \%)$ & 0,913 & $0,860-0,969$ & 0,662 \\
\hline Kurang & $2(100 \%)$ & $0(0 \%)$ & & & \\
\hline \multicolumn{6}{|c|}{ Ketersediaan sarana } \\
\hline Cukup & $89(94,7 \%)$ & $5(5,3 \%)$ & 10,171 & $2,217-46,662$ & 0,001 \\
\hline Kurang & $7(63,6 \%)$ & $4(36,9 \%)$ & & & \\
\hline \multicolumn{6}{|c|}{ Dukungan Keluarga } \\
\hline Ada & $81(94,2 \%)$ & $5(5,8 \%)$ & 4,320 & $1,038-17,972$ & 0,032 \\
\hline Tidak & $15(78,9)$ & $4(21,1 \%)$ & & & \\
\hline \multicolumn{6}{|c|}{ Dukungan Masyarakat } \\
\hline Ada & $85(91,4 \%)$ & $8(8,6 \%)$ & 0,966 & $0,110-8,474$ & 0,975 \\
\hline Tidak & $11(91,7 \%$ & $1(8,3 \%)$ & & & \\
\hline \multicolumn{6}{|l|}{ Masa Kerja } \\
\hline Lama & $87(94,6 \%)$ & $5(5,4 \%)$ & 7,733 & $1,755-34,078$ & 0,002 \\
\hline
\end{tabular}


Arc. Com. Health • Desember 2020

p-ISSN 2302-139X e-ISSN 2527-3620

Vol. 7 No. 2 : 21 - 34

Baru $\quad 9(69,2 \%) \quad 4(30,8 \%)$

Usia

Dewasa

Belum Dewasa

$91(94,8 \%) \quad 5(5,2 \%)$

14,560

2,959-71,647

0,000

Pengetahuan

Tinggi

$84(94,4 \%) \quad 5(5,6 \%)$

5,600

$1,317-23,808$

0,011

Rendah

$12(75,0 \%) \quad 4(25,0 \%)$

\section{Pengawasan}

Cukup

$80(95,2 \%) \quad 4(4,8 \%)$

6,250

$1,511-25,860$

0,005

Kurang

$16(76,2 \%) \quad 5(23,8 \%)$

Berdasarkan hasil Tabel .2 diketahui terdapat 8 variabel yang berpengaruh terhadap partisipasi kader Jumantik dalam melaksanakan PSN di Kecamatan Denpasar Selatan tahun 2019. Adapun kedelapan variabel tersebut antara lain tingkat pendidikan, penghasilan, ketersediaan sarana, dukungan keluarga, masa kerja, usia, pengetahuan dan pengawasan. Pada variabel tingkat pendidikan dari 105 responden, terdapat 91 responden yang tergolong dalam kategori berpendidikan tinggi (SMA ke atas). Dari 91 responden tersebut sebanyak 86 responden $(94,5 \%)$ berprilaku aktif dalam kegiatan PSN. Sedangkan responden yang tergolong ke dalam kategori tingkat pendidikan rendah terdapat 14 orang. Dari 14 responden tersebut sebanyak 10 orang $(71,4 \%)$ aktif dalam melaksanakan PSN. Berdasarkan hasil uji chi square diperoleh nilai $\mathrm{p}$ value $0,004(p<0,05)$, maka secara statistik tingkat pendidikan berpeluang mempengaruhi partisipasi kader Jumantik dalam melaksanakan kegiatan PSN. Degan nilai crude OR 6,880 hal ini menunjukkan kader
Jumantik yang memiliki tingkat pendidikan tinggi berpeluang 6,8 kali lebih aktif dibandingkan dengan kader Jumantik yang berpendidikan rendah.

Variabel penghasilan juga diketahui berpengaruh terhadap partisipasi kader Jumantik dalam melaksanakan kegiatan PSN. Dari 105 responden terdapat 51 responden yang menganggap penghasilan yang diterima selama bekerja sebagai kader Jumantik cukup. Dari 51 responden tersebut sebanyak 50 responden (98\%) aktif dalam melaksanakan kegiatan PSN. Sedangkan 54 responden lainnya menganggap penghasilan yang diterima sebagai kader Jumantik kurang cukup. Dari 54 responden tersebut sebanyak 46 responden $(86,2 \%)$ aktif dalam melaksanakan PSN. Berdasarkan hasil uji chi square diperoleh nilai $\mathrm{p}$ value 0,019 ( $p<0,05)$. Secara statistik hasil tersebut menunjukkan bahwa penghasilan berpengaruh terhadap meningkatkan partisipasi kader Jumantik dalam melaksanakan PSN. Dengan nilai crude OR 8,696 berarti kader Jumantik yang menganggap penghasilan yang diterima 
Vol. 7 No. $2: 21$ - 34

sebagai kader cukup berpeluang 8,6 kali lebih aktif dalam melaksanakan PSN dibandingkan kader yang menganggap penghasilan yang diterimanya sebagai kader kurang cukup.

Variabel ketersediaan sarana juga berpengaruh terhadap partisipasi kader Jumantik dalam melaksanakan PSN. Dari 105 responden, sebanyak 94 responden yang menganggap ketersedian sarana yang diberikan oleh pimpinan cukup untuk menunjang kegiatan PSN. Dari 94 responden tersebut sebanyak 89 responden (94,7\%) aktif dalam melaksanakan PSN. Sedangkan dari 11 responden yang menganggap ketersediaan sarana dianggap kurang sebanyak 7 responden (63,6\%) aktif dalam melaksanakan PSN. Berdasarkan uji chi square hasil nilai $\mathrm{p}$ value $0,001 \quad(\mathrm{p}<0,005)$. Dengan nilai crude OR 10,171 menunjukkan bahwa kader Jumantik yang menganggap ketersedian sarana yang diterima cukup berpeluang 10,1 kali lebih aktif dibandingkan kader yang menganggap ketersediaan sarana yang diterima kurang. Variabel selanjutnya yang berpengaruh terhadap keaktifan kader Jumantik dalam melaksanakan PSN adalah dukungan keluarga. Dari 105 responden, sebanyak 86 responden mendapat dukungan baik dari anggota keluarga. Dari 86 responden tersebut sebanyak 81 responden (94,2\%) berperilaku aktif dalam melaksanakan PSN. Sedangkan dari 19 sisa responden yang kurang mendapatkan dukungan baik dari keluarga sebanyak 15 orang $(78,9 \%)$ aktif dalam melaksanakan PSN. Berdasarkan uji chi square diperoleh nilai p 0,032 $(\mathrm{p}<0,05)$ dengan nilai crude $O R$ 4,320 menunjukkan bahwa kader Jumantik yang mendapatkan dukungan baik dari keluarga berpeluang aktif 4,3 kali dibandingkan kader yang kurang mendapat dukungan baik dari keluarga.

Variabel masa kerja juga diketahui berpengaruh terhadap perilaku aktif kader Jumantik dalam melaksanakan PSN di Kecamatan Denpasar Selatan. Dari 105 responden, sebanyak 92 responden tergolong memiliki masa kerja lama sebagai kader Jumantik. Dari 92 responden tersebut sebanyak 87 responden (94,6\%) tergolong aktif melaksanakan PSN. Sedangkan jumlah kader yang tergolong ke dalam masa usia kerja baru sebanyak 13 responden dan 9 diantaranya $(69,2 \%)$ tergolong aktif dalam melaksanakan PSN. Berdasarkan hasil uji chi square diperoleh nilai p $0,002(\mathrm{p}<0,05)$ dengan nilai crude OR 7,733 yang berarti kader Jumantik yang memiliki usia kerja lama berpeluang lebih aktif sebesar 7,7 kali dibandingkan kader Jumantik yang memiliki masa usia kerja baru.

Selanjutnya variabel usia juga diketahui berpengaruh terhadap keaktifan kader Jumantik dalam melaksanakan PSN. Dari 105 responden sebanyak 96 responden tergolong ke dalam kategori usia dewasa. Dari 96 responden tersebut sebanyak 91 responden (94,8\%) tergolong aktif dalam melaksanakan PSN. Sementara sebanyak 9 responden tergolong memiliki usia belum dewasa dan sebanyak 5 (55,6\%) diantaranya tergolong aktif dalam melaksanakan PSN. Berdasarkan hasil uji chi square diperoleh nilai $p$ value sebesar $0,000(p<0,05)$ dengan 
nilai crude OR 14,560 yang berarti kader Jumantik yang tergolong berusia dewasa memiliki peluang lebih aktif sebesar 14,5 kali dibandingkan kader jumantik yang tergolong ke dalam usia belum dewasa.

Variabel selanjutnya yang berbengaruh terhadap keaktifan kader Jumantik dalam melaksanakan PSN adalah pengetahuan. Dari 105 responden sebanyak 89 responden tergolong memiliki tingkat pengetahuan tinggi dan dari jumlah tersebut sebanyak 84 responden $(94,4 \%)$ tergolong aktif dalam melaksanakan PSN. Sementara 16 responden tergolong memiliki tingkat pendidikan rendah. Dari jumlah tersebut sebanyak 12 responden (75\%) tergolong aktif dalam melaksanakan PSN. Berdasarkan hasil uji chi square diperoleh nilai $\mathrm{p}$ value sebesar 0,011 ( $p<0,05)$. Dengan nilai crude OR 5,600 menunjukkan bahwa kader Jumantik yang tergolong memiliki tingkat pengetahuan tinggi memiliki peluang 5,6 kali lebih tinggi dibandingkan kader Jumantik yang tergolong memiliki tingkat pendidikan rendah.

Variabel terakhir yang berpengaruh terhadap keaktifan kader Jumantik dalam melaksanakan PSN adalah pengawasan dari pimpinan. Dari 105 responden sebanyak 84 responden menganggap mendapat pengawasan yang cukup dari pimpinan. Dari jumlah tersebut sebanyak 80 responden (95,2\%) berpartisipasi aktif dalam melaksanakan PSN. Sementara dari 21 responden yang menganggap kurang mendapat pengawasan cukup dari pimpinan sebanyak 16 responden $(76,2 \%)$ berpartisipasi aktif dalam melaksanakan PSN. Berdasarkan pada hasil uji chi square diperoleh nilai $p$ value sebesar $0,005(p<0,05)$. Dengan hasil nilai crude $O R$ sebesar 6,250 menunjukkan bahwa kader Jumantik yang mendapatkan pengawasan cukup dari pimpinan memiliki peluang 6,2 kali lebih aktif dibandingkan yang kurang mendapatkan pengawasan dari pimpinan.

Untuk variabel yang diketahui kurang berpengaruh terhadap partisipasi kader Jumantik dalam melaksanakan PSN terdapat dua variabel, yaitu pemberian penghargaan dan dukungan masyarakat. Pada variabel pemberian penghargaan dari 105 responden yang diwawancarai sebanyak 103 responden menganggap mendapat penghargaan yang cukup dari pimpinan. Dari jumlah tersebut sebanyak 94 responden (91,3\%) berpartisipasi aktif dalam melaksanakan PSN. Berdasarkan hasil uji chi square diperoleh nilai $\mathrm{p}$ sebesar 0,662 $(p>0,05)$ yang berarti Ho diterima dan tidak ada pengaruh antara variabel pemberian terhadap keaktifan kader Jumantik dalam melaksanakan PSN.

Hal yang sama juga terjadi pada variabel dukungan masyarakat, dari 105 responden yang diwawancarai sebanyak 93 responden menganggap mendapat dukungan baik dari masyarakat. Dari jumlah tersebut sebanyak 85 responden (91,4\%) diantaranya berpartisipasi aktif dalam melaksanakan PSN. Berdasarkan hasil uji chi square diperoleh nilai $\mathrm{p}$ sebesar 0,975 ( $p>0,05)$ yang berarti Ho diterima sehingga dapat disimpulkan bahwa tidak ada 
pengaruh antara dukungan masyarakat terhadap keaktifan kader Jumantik dalam melaksanakan PSN.

\section{DISKUSI}

Dalam penelitian ini jumlah responden yang diwawancarai sebanyak 105 responden. Jumlah tersebut sesuai dengan jumlah kader Jumantik yang terdaftar di wilayah kerja Puskesmas di Kecamatan Denpasar Selatan. Dari 105 responden tersebut diketahui jumlah kader Jumantik yang tergolong memiliki tingkat partisipasi aktif sebanyak 96 orang atau sebesar $91,6 \%$ sedangkan jumlah kader yang tergolong memiliki tingkat partisipasi kurang aktif sebanyak 9 orang atau sebsesar 8,6\%. Dari 10 variabel yang diuji diperoleh hasil sebanyak 8 variabel berpengaruh terhadap partisipasi kader Jumantik dalam melaksanakan PSN di Kecamatan Denpasar Selatan, antara lain variabel tingkat pendidikan, penghasilan, ketersediaan sarana, dukungan keluarga, masa kerja, usia, pengetahuan dan pengawasan. Sedangkan variabel pemberian penghargaan dan dukungan masyarakat diketahui tidak berpengaruh terhadap partisipasi kader Jumantik di Kecamatan Denpasar Selatan dalam melaksanakan PSN.

Dalam hasil uji chi square, variabel tingkat pendidikan mendapatkan nilai $p$ value sebesar 0,004. Hasil tersebut menunjukkan bahwa Ho ditolak yang berarti ada pengaruh antara tingkat pendidikan dengan keaktifan kader Jumantik dalam melaksanakan PSN. Dalam penelitian ini tingkat pendidikan responden dibedakan menjadi 2, yaitu tinggi bagi responden yang mengenyam pendidikan SMA/Sederajat dan di atasnya dan kategori rendah bagi responden yang mendapatkan pendidikan setingkat SMP/Sederajat dan di bawahnya. Sebagian besar responden dalam penelitian ini tergolong ke dalam kategori pendidikan tinggi, yaitu 91 responden $(86,7 \%)$ dengan rincian 90 responden dari lulusan SMA/Sederajat dan 1 orang responden lulusan Diploma 1. Responden dengan tingkat pendidikan tinggi terbukti lebih aktif partisipasinya dalam melaksanakan PSN. Hal tersebut dikarenakan informasi dan perubahan sikap responden yang memiliki tingkat pendidikan tinggi akan lebih baik dibandingkan dengan responden dengan pendidikan rendah (Notoadmodjo, 2010).

Hal ini juga sejalan dengan teori (George, 2014) yang mengemukakan bahwa pendidikan merupakan suatu usaha sadar untuk menyiapkan peserta didik melalui kegiatan bimbingan, latihan dan pengajaran bagi peranannya di masa yang akan datang. Teori tersebut juga menyatakan bahwa kenaikan tingkat pendidikan akan diikuti dengan kenaikan kinerja karyawan tersebut secara signifikan. Penelitian (Gooderham et all, 2018) juga memperoleh hasil bahwa tingkat pendidikan berpengaruh pada kinerja karyawan. Pendidikan disebutkan sebagai faktor yang mencerminkan seseorang dalam menyelesaikan tugasnya. Dengan menempuh tingkat pendidikan tertentu, menyebabkan seorang pegawai memiliki tingkat pengetahuan tertentu sehingga mampu untuk menyelesaikan tugasnya dengan baik. Dengan demikian 
maka pendidikan diketahui berpengaruh terhadap keaktifan kinerja para pekerja.

Sesuai dengan hasil uji chi square terhadap variabel penghasilan diketahui bahwa variabel penghasilan berpengaruh terhadap partisipasi aktif kader Jumantik dalam melaksanakan PSN di Kecamatan Denpasar Selatan. Hasil ini juga sesuai dengan pendapat (Stolovitch \& Keeps, 2011) yang menyatakan bahwa tingkat kinerja karyawan sangat berkaitan dengan besaran upah yang diterima selama bekerja di perusaan tersebut. Variabel ketersediaan sarana juga diketahui berpengaruh terhadap partisipasi aktif dari kader Jumantik dalam melaksanakan PSN di Kecamatan Denpasar Selatan. Berdasarkan hasil uji chi square diperoleh nilai $\mathrm{p}$ value sebesar 0,001 . Hasil tersebut menunjukkan Ho ditolak yang berarti bahwa ketersediaan sarana berpengaruh dalam keaktifan kader dalam melaksanakan PSN. Hasil ini sejalan dengan penelitian yang dilakukan oleh (Ambarwati \& Suryani, 2014) yang menyatakan bahwa ketersediaan sarana yang cukup dapat meningkatkan partisipasi kerja perangkat desa di Kecamatan Wonoboyo, karena dengan ketersediaan sarana yang cukup pekerja merasa diperhatikan dan mendapat dukungan dari perusahaan dalam melaksanakan pekerjaannya sehingga akan memotivasi mereka untuk bekerja lebih giat.

Dukungan keluarga merupakan variabel selanjutnya yang berpengaruh terhadap partisipasi aktif kader Jumantik dalam melaksanakan PSN di Kecamatan Denpasar Selatan. Berdasarkan hasil uji chi square diperoleh nilai $\mathrm{p}$ value sebesar 0,032 $(p<0,05)$. Hal ini sejalan dengan pendapat yang dikemukakan (Friedman, 2010) bahwa dukungan baik dari keluarga dapat meningkatkan semangat kerja, menumbuhkan kepercayaan diri dan mengurangi stress dalam bekerja. Variabel masa kerja juga berpengaruh terhadap partisipasi aktif kader Jumantik dalam melaksanakan PSN di Kecamatan Denpasar Selatan. Hasil uji chi square variabel masa kerja mendapatkan nilai $\mathrm{p}$ value sebesar 0,002 ( $p<0,05)$. Hasil tersebut berarti Ho ditolak dan dapat disimpulkan bahwa ada pengaruh antara masa kerja dengan partisipasi aktif kader Jumantik dalam melaksanakan PSN. Nilai odd ratio yang diperoleh pada variabel masa kerja adalah 7,733 (interval keyakinan 95\%, 1,755-34,078). Hasil tersebut menunjukkan kader Jumantik dengan masa usia kerja lama 7,7 kali berpeluang lebih aktif dibandingkan dengan kader Jumantik dengan masa usia kerja baru. Hasil tersebut sejalan dengan penelitian (Nicholas et all, 2017) bahwa orang yang memiliki usia kerja lama akan memiliki pengalaman kerja yang lebih banyak dan juga diikuti dengan peningkatan partisipasi dan kepandaian dalam menghadapi permasalahan di dunia kerja.

Berdasarkan hasil uji chi square pada variabel usia diperoleh nilai $p$ value 0,000 $(p<0,05)$. Hasil tersebut berarti Ho ditolak dan dapat disimpulkan bahwa usia berpengaruh terhadap partisipasi aktif kader Jumantik dalam melaksanakan PSN. Hasil ini sesuai dengan penelitian yang dilakukan 
Vol. 7 No. 2 : 21 - 34

(Barker, 2009) bahwa usia mempengaruhi pola pikir manusia dan juga perilakunya termasuk dalam bekerja. Berdasarkan hasil uji chi square nilai $\mathrm{p}$ value yang diperoleh pada variabel pengetahuan adalah 0,011 $(p<0,05)$. Hasil ini menunjukkan Ho ditolak yang berarti tingkat pengetahuan berpengaruh terhadap partisipasi kader Jumantik dalam melaksanakan PSN. Berdasarkan hasil uji chi square nilai odd ratio yang diperoleh, yaitu 5,600 (dengan interval keyakinan 95\%, 1,313-23,808) hal ini berarti kader Jumantik dengan tingkat pengetahuan tinggi 5,6 kali berpeluang lebih aktif dibandingkan dengan kader Jumantik dengan tingkat pengetahuan rendah. Hasil penelitian ini juga sejalan dengan penelitian yang dilakukan (Wahyu et all, 2014) yang menyatakan bahwa pengetahuan karyawan menjadi variabel yang paling berpengaruh dalam peningkatan partisipasi kinerja karyawan. Penelitian (Priminiano et all, 2015) juga mengungkap bahwa pekerja yang memiliki pengetahuan di bidangnya cenderung akan memiliki partisipasi lebih aktif.

Berdasarkan hasil uji chi square pada variabel pengawasan diperoleh nilai $p$ value 0,005 ( $\mathrm{p}<0,05)$. Hasil tersebut berarti Ho ditolak dan dapat disimpulkan bahwa ada pengaruh antara pengawasan terhadap partisipasi aktif kader Jumantik dalam melaksanakan PSN. Hasil nilai odd ratio yang diperoleh adalah 6,250 (tingkat keyakinan 95\%, 1,511-25,860) yang berarti kader Jumantik yang menganggap mendapat pengawasan cukup dari pimpinan 6,2 kali berpeluang lebih aktif dibandingkan dengan yang menganggap kurang mendapatkan dukungan cukup dari pimpinan. Hasil penelitian ini juga sejalan dengan penelitian yang dilakukan oleh (Schuh et all, 2017) yang menyimpulkan bahwa faktor pengawasan dari pimpinan merupakan salah satu faktor yang berpengaruh terhadap partisipasi kerja karyawan.

Berdasarkan hasil uji chi square diperoleh nilai $p$ value $0,662(p>0,05)$ pada variabel pemberian penghargaan. Hasil tersebut berarti Ho diterima dan dapat disimpulkan bahwa pemberian penghargaan tidak signifkan mempengaruhi partisipasi kader Jumantik dalam melaksanakan PSN. Hasil tersebut mematahkan pendapat yang dikemukakan (Bangun, 2012) yang menyatakan pemberian apresiasi tertentu pada karyawan dapat meningkatkan minat karyawan tersebut dalam bekerja. Hasil yang sama juga ditemui pada variabel dukungan masyarakat dimana berdasarkan hasil uji chi square nilai $\mathrm{p}$ value yang diperoleh 0,975 ( $p>0,05)$. Hasil tersebut menunjukkan Ho diterima yang berarti tidak ada pengaruh antara dukungan masyarakat terhadap partisipasi kader Jumantik dalam melaksanakan PSN di Kecamatan Denpasar Selatan.

\section{SIMPULAN}

Berdasarkan pada hasil penelitian ini diketahui bahwa sebagian besar kader Jumantik di Kecamatan Denpasar Selatan tergolong memiliki partisipasi aktif, yaitu sebanyak 96 orang (91,4\%) sedangkan sebanyak 9 orang $(8,6 \%)$ sisanya tergolong kurang aktif dalam melaksanakan PSN. 
Faktor-faktor yang berpengaruh terhadap keaktifan kader Jumantik di Kecamatan Denpasar Selatan dalam melaksanakan PSN, antara lain faktor tingkat pendidikan, penghasilan, ketersediaan sarana, dukungan keluarga, masa kerja, usia, pengetahuan dan pengawasan dari pimpinan. Sedangkan faktor dukungan masyarakat dan pemberian penghargaan tidak berpengaruh terhadap partisipasi kader Jumantik dalam melaksanakan PSN di Kecamatan Denpasar Selatan

\section{SARAN}

Untuk meningkatkan partisipasi kader Jumantik diharapkan Dinas Kesehatan Kota Denpasar dapat memberikan penghasilan sesuai dengan beban kerja yang dilakukan oleh kader Jumantik dan memberikan pemahaman kepada kader apabila jumlah penghasilan yang mereka terima sudah sesuai dengan beban kerjanya saat ini, menjaring kader Jumantik yang memiliki tingkat pendidikan minimal SMA untuk memudahkan komunikasi dan pemberian pemahaman dalam bekerja, menyediakan sarana dan prasarana yang cukup, baik secara kualitas maupun kuantitas, menginstruksikan kepada para koordinator maupun supervisor DBD untuk meningkatkan pengawasan bagi para kader serta memberikan pelatihan maupun metode edukasi lain seperti penyegaran kader untuk meningkatkan pengetahuan kader tentang penyakit DBD dan upaya pencegahannya.

Bagi kader Jumantik yang tergolong kurang aktif diharapkan untuk memperbaiki kinerjanya dan mengingat kembali tugas pokok dan fungsinya saat pertama kali diangkat sebagai kader Jumantik dan mengaplikasikannya di lapanngan sebagai bentuk tanggung jawab terhadap pekerjaan serta pengabdian kepada Desa/Kelurahannya masing-masing untuk dapat menurunkan angka kasus DBD di Kecamatan Denpasar Selatan.

\section{DAFTAR PUSTAKA}

Ambarwati \& Suryani (2014) 'Pengaruh Komunikasi Internal, Motivasi Kerja dan Fasilitas Kerja Terhadap Kinerja Perangkat Desa di Kecamatan Wonoboya Kabupaten Temanggung', Economic Education Analysis Journal, 3, pp. 299-306.

Bangun, W. (2012) Manajemen Sumber Daya Manusia. Jakarta: Erlangga.

Barker, V. (2009) 'Older Adolescents Motivations For Social Network Site Use : The Influence Of Gender, Group Identity and Collective Self-Esteem', 42, pp. 133-151.

Friedman, M. (2010) Buku Ajar Keperawatan Keluarga. 5th edn. Jakarta: EGC.

George, F. K. (2014) Politic Ideologies dalam George F Kneller (ed). New York: Foundations Of Education.

Gooderham, P., Croucher, R., \& Brookes, M. (2018) 'A Multilevel Analylis Of The Use Of Individual Pay-ForPerformance System', Journal Of Management, 44, pp. 1479-1504.

Murti, B. (2006) Desain Ukuran Sampel Untuk Penelitian Kuntitatif dan Kualitatif di 
Bidang Kesehatan. Yogyakarta: UGM Press.

Nicholas, W., Hicklin, A., \& Crespin, V. (2017) 'Evaluating The Impact Of Performance Funding In Ohio And Tennessee', American Educational Research Journal, 55, pp. 144-170.

Notoadmodjo, S. (2010) Metode Penelitian Kesehatan. Jakarta: Rineka Cipta.

Priminiano, D., Merola, B., \& Caputo, F. (2015) 'Reflections On The Role Of University To Face The Challenge Of Knowledge Society For The Local Economic Development', 4, pp. 7796.

Schuh, S., Xinan, Z., \& Frederick, P. (2017) 'Interractive Effect Of Employee Innovative Work Behavior And Leader-Member Exchange On Supervisory Performance Rating', 57, pp. 397-409.

Stolovitch \& Keeps (2011) Performance Appraisal dalam Veitzhal Rivai. Jakarta: PT. Rajagrafindo.

Sukowati, S. (2010) Demam Berdarah Dengue. Jakarta: Buletin Jendela Epidemiologi.

Wahyu, Ardimas \& Wardoyo (2014) 'Pengaruh Kinerja Keuangan dan Corporate Social Responbility Terhadap Nilai Perusahaan Pada Bank Go Public Yang Terdaftar di BEI', 42, p. 121135. 